\title{
DUALISME MODEL PENGUJIAN PERATURAN DAERAH PASCA UNDANG-UNDANG NOMOR 11 TAHUN 2020 TENTANG CIPTA KERJA
}

\author{
DUALISM OF REVIEW MODEL ON REGIONAL REGULATIONS \\ POST ACT NUMBER 11 OF 2020 ONJOB CREATION
}

\author{
Nurul Aprianti \\ Universitas Brawijaya, Malang \\ Email: nurulaprianti@student.ub.ac.id \\ Muchamad Ali Safa'at \\ Universitas Brawijaya, Malang \\ Email: safaat@ub.ac.id \\ Indah Dwi Qurbani \\ Universitas Brawijaya, Malang \\ Email: indah.qurbani80@ub.ac.id
}

\begin{abstract}
This paper aims specifically to outline the norm validity in Article 181 paragraph (2) Chapter XIII of Act Number 11 of 2020 on Job Creation associated with the review model on regional regulations through judicial review. This act regulates the harmonization and synchronization of regional regulations carried out by the Government. Meanwhile, according to Article 24A paragraph (1) of the 1945 Constitution of the Republic of Indonesia, the authority to examine statutory regulations under the law against the law is in the hand of the Supreme Court through a judicial review mechanism. This is also confirmed by the Constitutional Court in its Decisions Number 137/PUU-XIII/2015 and Number 56/PUU-XIV/2016 regarding the norm cancellation of regional regulation review by the Government. The research method used was normative legal research. The analysis was carried out using a statutory approach and then analyzed based on the related legal theory. The result of this research was that the norms of Article 181 paragraph (2) Chapter XIII of Act Number 11 of 2020 on Job Creation is invalid. The mechanism concept for harmonization and synchronization of regional regulation carried out by the Government should be limited when it is still in the form of draft in order to actualize the legal certainty so that the law enforcement becomes more effective and efficient.
\end{abstract}

Keywords: Dualism; Model; Review

\begin{abstract}
Abstrak
Tulisan bertujuan untuk menguraikan secara khusus tentang validitas norma dalam Pasal 181 ayat (2) Bab XIII Undang-Undang Nomor 11 Tahun 2020 tentang Cipta Kerja yang dikaitkan dengan model pengujian peraturan daerah melalui judicial review. Ketentuan tersebut mengatur mengenai harmonisasi dan sinkronisasi peraturan daerah yang dilakukan oleh Pemerintah. Adapun menurut Pasal 24A ayat (1) UUD NRI Tahun 1945 kewenangan menguji peraturan perundang-undangan di bawah Undang-Undang terhadap Undang-Undang berada di tangan Mahkamah Agung melalui mekanisme judicial review. Hal tersebut juga ditegaskan oleh
\end{abstract}


Mahkamah Konstitusi dalam Putusan Nomor 137/PUU-XIII/2015 dan Nomor 56/PUU$\mathrm{XIV} / 2016$ terkait pembatalan norma pengujian peraturan daerah oleh Pemerintah. Metode penelitian yang digunakan adalah penelitian hukum normatif. Analisis dilakukan dengan menggunakan pendekatan perundang-undangan kemudian dianalisis berdasarkan teori hukum yang terkait. Hasil kajian penelitian ini adalah bahwa norma Pasal 181 ayat (2) Bab XIII Undang-Undang Nomor 11 Tahun 2020 tentang Cipta Kerja tersebut invalid. Konsep mekanisme harmonisasi dan sinkronisasi peraturan daerah yang dilakukan oleh Pemerintah alangkah sebaiknya dibatasi pada saat masih berupa rancangan peraturan daerah. Hal tersebut guna untuk mewujudkan kepastian hukum sehingga penegakan hukum menjadi lebih efektif dan efisien.

\section{Kata Kunci: Dualisme; Model; Pengujian}

\section{PENDAHULUAN}

Kehadiran Undang-Undang Nomor 11 Tahun 2020 tentang Cipta Kerja menimbulkan kontroversi dalam kehidupan bernegara. Reaksi penolakan dari segenap elemen masyarakat muncul bahkan sejak masih berupa draft Rancangan Undang-Undang (RUU). Penolakan tersebut didasarkan pada argumentasi bahwa kehadiran RUU Cipta Kerja ini justru sebaliknya mempercepat pertumbuhan ekonomi hanya bagi sektor privat dan justru berpotensi untuk mementingkan kelompok atau golongan tertentu. Mengutip dari laman hukum online terdapat 7 (tujuh) dampak yang akan ditimbulkan terhadap pengesahan RUU Cipta Kerja bagi publik. Pertama, meluruhkan kewibawaan konstitusi dikarenakan terdapat 31 pasal yang telah dinyatakan inkonstitusional dihidupkan kembali. Kedua, resentralisasi dan otoriter, bahkan anti demokrasi karena menjauhkan pelayanan publik dan partisipasi. Keempat, instrument perizinan yang diatur dalam RUU Cipta Kerja yang lebih dominan kepada investor daripada memperhatikan dampak sosial dan lingkungan hidup. Kelima, adanya bias pengusaha yang dikarenakan sanksi untuk pengusaha bentuknya administratif dan kriminalisasi terhadap masyarakat yang semakin kuat. Keenam, jauh dari semangat antikorupsi karena adanya imunitas pejabat pengelola investasi. Ketujuh, berpotensi melahirkan celah legislasi perampasan tanah. ${ }^{1}$ Reaksi penolakan terhadap RUU Cipta Kerja semakin gencar mengingat bahwa UndangUndang tersebut dibentuk dengan metode omnibus law.

Webster menguraikan bahwa omnibus law adalah produk hukum yang merevisi beberapa aturan hukum sekaligus melalui aturan payung, disebut sebagai aturan payung karena omnibus law secara hierarki perundangan yang sudah mengalami komplikasi (tumpang tindih). Stuhring dalam jurnal Yale Law Review menyebutkan bahwa upaya omnibus law tidak hanya sekedar menyederhanakan maupun mengurangi peraturan perundangan melalui pembentukan aturan payung, melainkan harus disertai dengan penataan kewenangan. Konflik antar peraturan perundangan yang mengakibatkan tumpang tindih telah menghambat investasi dan pembangunan sesungguhnya yang bersumber pada konflik kewenangan. ${ }^{2}$ Berdasarkan pendapat tersebut maka dapat dipahami bahwa Undang-Undang Nomor 11 Tahun 2020 tentang Cipta Kerja merupakan payung hukum yang merevisi dan menyederhanakan beberapa aturan hukum terkait yang disertai dengan penataan kewenangan. Salah satu alasan penolakan terhadap Undang-Undang ini ialah adanya upaya menghidupkan kembali pasal yang telah dinyatakan inkonstitusional. Pada tulisan ini membahas mengenai ketentuan Pasal

\footnotetext{
${ }^{1}$ Ady Thea DA, "Ini Tujuh Dampak Negatif RUU Cipta Kerja Terhadap Publik", https://www.hukumonline. $\mathrm{com} /$ berita/baca/lt5f11d8eae4bba/ini-tujuh-dampak-negatif-ruu-cipta-kerja-terhadap-publik/, diakses 10 September 2020 .

${ }^{2}$ Rio Christiawan, 2021, Omnibus Law Teori Dan Penerapannya, Cet. Ke-1, Sinar Grafika, Jakarta, hlm. 3.
} 
181 ayat (2) Bab XIII tentang Ketentuan Lain-Lain dalam Undang-Undang Nomor 11 Tahun 2020 tentang Cipta Kerja yang memberikan kewenangan kepada Kementerian atau lembaga yang menyelenggarakan urusan pemerintahan di bidang pembentukan peraturan perundang-undangan serta Kementerian yang menyelenggarakan urusan pemerintahan dalam negeri untuk melakukan harmonisasi dan sinkronisasi peraturan daerah dan/atau peraturan kepala daerah.

Ketentuan tersebut diatas tentunya mengingatkan kita tentang ribuan peraturan daerah dan/atau peraturan kepala daerah yang telah dibatalkan oleh Kementerian Dalam Negeri. Pada tanggal 21 Juni 2016 Kementerian Dalam Negeri mengumumkan sebanyak 3.143 Peraturan Daerah yang dibatalkan. Pembatalan tersebut dinilai menghambat pertumbuhan ekonomi daerah dan memperpanjangjalurbirokrasi, menghambatinvestasi dan kemudahan berusaha. ${ }^{3}$ Alasan pembatalan peraturan daerah dan/atau peraturan kepala daerah tersebut tentunya sejalan dengan semangat dan tujuan dibentuknya Undang-Undang Nomor 11 Tahun 2020 tentang Cipta Kerja ini yakni dalam rangka mempercepat pertumbuhan ekonomi melalui kemudahan investasi. Sehingga muncul asumsi bahwa kehadiran Pasal 181 ayat (2) pada Bab XIII dalam Undang-Undang Nomor 11 Tahun 2020 tentang Cipta Kerja ini merupakan upaya untuk menghidupkan kembali ketentuan yang telah dinyatakan inkonstitusional oleh Mahkamah Konstitusi melalui 2 (dua) putusannya. Kedua putusan tersebut diantaranya melalui Putusan Mahkamah Konstitusi Nomor 137/PUU-XIII/2015 dan Putusan Mahkamah Konstitusi Nomor 56/ PUU-XIV/2016.

Mahkamah Konstitusi dalam 2 (dua) putusannya yaitu Putusan Mahkamah Konstitusi Nomor 137/PUU-XIII/2015 dan Putusan Mahkamah Konstitusi Nomor 56/PUUXIV/2016 Mahkamah Konstitusi memberikan tafsir atas ketentuan Pasal 251 ayat (1), (4), (5) dan (7) Undang-Undang Nomor 23 Tahun 2014 tentang Pemerintahan Daerah yang menyatakan bahwa Menteri Dalam Negeri tidak lagi dapat membatalkan peraturan daerah tingkat provinsi. ${ }^{4}$ Melalui kedua putusan tersebut, Mahkamah Konstitusi juga menegaskan bahwa pengujian peraturan daerah merupakan kewenangan yang dimiliki oleh Mahkamah Agung. Penelitian ini khususnya membahas mengenai validitas norma dalam ketentuan Pasal 181 ayat (2) Bab XIII Undang-Undang Nomor 11 Tahun 2020 tentang Cipta Kerja berdasarkan teori kewenangan. Penelitian ini bertujuan untuk menganalisis mengenai validitas norma hukum dalam ketentuan pasal yang mengamanatkan kewenangan untuk melakukan harmonisasi dan sinkronisasi peraturan daerah oleh Pemerintah. Adapun penelitian terkait pernah dilakukan oleh beberapa peneliti; pertama, Muhamad Nurhasan dalam tulisannya yang berjudul "Pembatalan Kewenangan Executive Review Pada Kementerian Dalam Negeri (Studi Analisa Putusan Mahkamah Konstitusi Nomor 56/PUU-XIV/2016)" yang membahas mengenai pembatalan kewenangan untuk membatalkan peraturan daerah oleh Kementerian Dalam Negeri dan Gubernur akan tetapi hanya terbatas pada peraturan daerah dan tidak menjangkau pada peraturan kepala daerah. ${ }^{5}$ Kedua, Ahmad Bonadi, dkk dalam tulisannya yang berjudul "Analisis Putusan Mahkamah Konstitusi Nomor: 137/PUUXIII/2015 Tentang Pembatalan Kewenangan Gubernur Dalam Membatalkan Peraturan

\footnotetext{
${ }^{3}$ Luqman Rimadi, 3.143 Perda yang Dibatalkan Bisa Dilihat di Situs Kemendagri, https://www.liputan6.com/ news/read/2536897/3143-perda-yang-dibatalkan-bisa-dilihat-di-situs-kemendagri, diakses 13 Oktober 2020.

${ }^{4}$ Almas Sidda Bahiya, 2020, Executive Review Sebagai Langkah Peningkatan Kualitas Peraturan Daerah di Indonesia, Moechthar Oemar (Ed), Eksistensi, Fungsi dan Tujuan Hukum Dalam Perspektif Teori dan Filsafat Hukum, Kencana, Jakarta, hlm. 383-384.

${ }^{5}$ Muhamad Nurhasan, Pembatalan Kewenangan Executive Review Pada Kementerian Dalam Negeri (Studi Analisis Putusan Mahkamah Konstitusi Nomor 56/PUU-XIV/2016), Skripsi, Fakultas Syariah Dan Hukum Universitas Islam Syarif Hidayatullah Jakarta, 2018, hlm.74.
} 
Daerah Kabupaten/Kota" yang membahas mengenai adanya peningkatan beban perkara di Mahkamah Agung dengan dibatalkannya kewenangan Gubernur dan Kementerian Dalam Negeri untuk membatalkan peraturan daerah. Selain itu dampak lainnya ialah menghambat deregulasi dan percepatan pembangunan. Ketiga, Eka Nam Sihombing dalam tulisannya yang berjudul "Perkembangan Kewenangan Pembatalan Peraturan Daerah Dan Peraturan Kepala Daerah (Kajian Putusan Mahkamah Konstitusi Nomor 137/PUU-XIII/2015 dan Nomor 56/PUU-XIV/2016) menyatakan bahwa kedua putusan Mahkamah Konstitusi tersebut tidak serta merta menyelesaikan masalah. Hal tersebut dikarenakan kewenangan pembatalan hanya berlaku bagi peraturan daerah provinsi dan kabupaten/kota akan tetapi tidak berlaku pada peraturan kepala daerah. Pada penelitian tersebut menegaskan arti penting dari pengawasan regulasi antar pusat dan daerah akan tetapi melalui penguatan executive preview bukan executive review. Keempat, Devyanti Ramadhani dalam tulisannya yang berjudul "Kewenangan Pembatalan Peraturan Daerah Pada Tahapan Evaluasi Dan Klarifikasi" menyatakan bahwa terkait kewenangan pembatalan peraturan daerah yang dilakukan oleh Kementerian Dalam Negeri sesungguhnya telah melampaui kewenangan yang seharusnya menjadi kewenangan Presiden dengan instrument Peraturan Presiden. Kelima, Wahyu Tri Hartono dalam tulisannya yang berjudul "Implikasi Putusan Mahkamah Konstitusi Nomor 137/PUU-XIII/2015 Dan Putusan Nomor 56/PUU-XIV/2016 Tentang Pembatalan Peraturan Daerah Provinsi, Peraturan Daerah Kabupaten/Kota, Peraturan Gubernur, Dan Peraturan Bupati/Peraturan Walikota" menyatakan bahwa adanya dampak positif terhadap kepastian hukum terhadap kewenangan pembatalan produk hukum daerah yang sebelumnya berpotensi menimbulkan dualisme putusan.

Berdasarkan penelitian di atas maka peneliti tertarik untuk membahas mengenai mekanisme harmonisasi dan sinkronisasi peraturan daerah yang dilakukan oleh Pemerintah sebagaimana diamanatkan dalam Pasal 181 Bab XIII Undang-Undang Nomor 11 Tahun 2020 tentang Cipta Kerja apakah memiliki kesamaan atau perbedaan dengan mekanisme executive review pada peraturan daerah sebagaimana yang telah dibatalkan oleh Mahkamah Konstitusi melalui 2 (dua) putusannya beserta implikasinya. Untuk menjawab permasalahan tersebut maka dilakukan penelitian dengan metode penelitian hukum normatif. Adapun pendekatan yang digunakan ialah pendekatan peraturan perundang-undangan (statuta approach) dengan melakukan telaah terkait peraturan perundang-undangan terkait. Sedangkan pendekatan teoritis dilakukan untuk menganalisis norma-norma dalam aturan yang terkait berdasarkan teori hierarki norma dan teori kewenangan. Analisis bahan hukum dalam penelitian dilakukan secara kualitatif. Bahan hukum yang telah terkumpul baik primer, sekunder maupun tersier dianalisis menggunakan instrument teori.

\section{PEMBAHASAN}

\section{Implikasi Pasal 181 Ayat (2) BAB XIII Undang-Undang Nomor 11 Tahun 2020 Tentang Cipta Kerja.}

Salah satu alasan penolakan terhadap Undang-Undang ini ialah adanya upaya untuk menghidupkan kembali pasal yang telah dinyatakan inkonstitusional oleh Mahkamah Konstitusi. Adapun rumusan Pasal 181 Bab XIII Undang-Undang Cipta Kerja yang menyatakan bahwa:

(1) Pada saat berlakunya Undang-Undang ini, setiap peraturan perundang-undangan di bawah Undang-Undang yang berlaku dan bertentangan dengan ketentuan 
Undang-Undang ini atau bertentangan dengan peraturan perundang-undangan yang lebih tinggi, atau bertentangan dengan putusan pengadilan harus dilakukan harmonisasi dan sinkronisasi yang dikoordinasikan oleh kementerian atau lembaga yang menyelenggarakan urusan pemerintahan di bidang pembentukan peraturan perundang-undangan.

(2) Harmonisasi dan sinkronisasi yang berkaitan dengan peraturan daerah dan/ atau peraturan kepala daerah, dilaksanakan oleh kementerian atau lembaga yang menyelenggarakan urusan pemerintahan di bidang pembentukan peraturan perundang-undanganbersama dengan kementerianyang menyelenggarakanurusan pemerintahan dalam negeri.

(3) Ketentuan lebih lanjut mengenai harmonisasi dan sinkronisasi sebagaimana dimaksud pada ayat (1) dan ayat (2) diatur dalam Peraturan Pemerintah. ${ }^{6}$

Berdasarkan ketentuan tersebut di atas memang tidak ada terdapat kata "menguji" atau "membatalkan". Akan tetapi yang kita dijumpai ialah kata "harmonisasi" dan "sinkronisasi". Istilah harmonisasi sebagaimana dikutip oleh Erik Sepria dalam Kamus Besar Bahasa Indonesia terbitan Balai Pustaka, berasal dari kata harmoni yang berarti keselarasan dan keserasian. Sedangkan kata harmonisasi adalah upaya untuk mencari keselarasan. Adapun harmonisasi peraturan perundang-undangan ialah upaya atau proses untuk merealisasikan keselarasan dan keserasian asas dan sistem hukum sehingga menghasilkan peraturan (sistem hukum) yang harmonis. ${ }^{7}$

Adapun menurut Badan Pembinaan Hukum Nasional (BPHN) memberikan pengertian sebagai berikut: ${ }^{2}$

"Harmonisasi hukum adalah kegiatan ilmiah untuk menuju proses pengharmonisasian hukum tertulis yang mengacu pada nilai-nilai filosofis, sosiologis, ekonomis maupun yuridis. Dalam pelaksanaanya, kegiatan harmonisasi adalah pengkajian yang komprehensif terhadap suatu rancangan peraturan perundang-undangan dengan tujuan untuk mengetahui suatu rancangan peraturan tersebut dalam berbagai aspek telah mencerminkan keselarasan atau kesesuaian dengan peraturan perundang-undangan nasional lain, dengan hukum tidak tertulis yang hidup dalam masyarakat, atau dengan konvensi-konvensi dan perjanjian-perjanjian internasional, baik bilateral maupun multibilateral yang diratifikasi oleh Pemerintah RI".

Selain itu harmonisasi hukum adalah mencakup penyesuaian peraturan perundangundangan, keputusan pemerintah, keputusan hakim, sistem hukum dan asas-asas hukum dengan tujuan peningkatan kesatuan hukum, kepastian hukum, keadilan dan kesebandingan kegunaan dan kejelasan hukum tanpa mengaburkan dan mengorbankan pluralism hukum. Hal ini senada disampaikan oleh Moh. Hasan Wangkusumah, harmonisasi hukum sebagai kegiatan ilmiah untuk menuju proses pengharmonisasian hukum tertulis yang mengacu baik pada nilai-nilai filosofis, sosiologis, ekonomis maupun yuridis. ${ }^{9}$

Adapun sinkronisasi adalah penyelarasan dan penyelerasian berbagai peraturan perundang-undangan yang terkait dengan peraturan perundang-undangan yang telah ada dan yang sedang disusun yang mengatur suatu bidang tertentu. Proses

\footnotetext{
${ }^{6}$ Pasal 181 Bab XIII Undang-Undang Nomor 11 Tahun 2020 tentang Cipta Kerja, Lembaran Negara Republik Indonesia Tahun 2020 Nomor 245, Tambahan Lembaran Negara Republik Indonesia Nomor 6573.

${ }^{7}$ Erik Sepria, 2017, Sinkronisasi dan Harmonisasi Pembentukan Regulasi Pusat Dengan Daerah Dalam Rangka Penataan Regulasi Sebagai Pelaksanaan Otonomi Daerah di Indonesia, Biro Pengkajian (Ed.), Strategi Perampingan Dan Harmonisasi Regulasi Pusat Dan Daerah, Majelis Permusyawaratan Rakyat Republik Indonesia, Jakarta, hlm 141.

${ }^{8}$ Ibid.,

${ }^{9}$ Ibid, hlm. 142.
} 
sinkronisasi peraturan bertujuan untuk melihat adanya keselarasan antara peraturan yang satu dengan peraturan lainnya. Maksud dari kegiatan sinkronisasi adalah agar substansi yang diatur dalam produk perundang-undangan tidak tumpang tindih, saling melengkapi (suplementer), saling terkait dan semakin rendah jenis pengaturannya maka semakin detail dan operasional materi muatannya. ${ }^{10}$ Selain itu tujuan dari sinkronisasi hukum adalah untuk mewujudkan landasan pengaturan di bidang tertentu yang dapat memberikan kepastian hukum yang memadai bagi penyelenggaraan bidang tersebut secara efektif. ${ }^{11}$

Selanjutnya sinkronisasi peraturan perundang-undangan dilakukan melalui 2 (dua) cara yaitu: ${ }^{12}$

- Sinkronisasi vertikal dilakukan dengan melihat apakah ada pertentangan norma antar aturan yang satu dengan aturan yang lain di bidang tertentu. Selain memperhatikan hierarki peraturan, sinkronisasi vertikal juga harus memperhatikan kronologis tahun dan nomor penetapan peraturan perundang-undangan yang terkait.

- Sinkronisasi horizontal dilakukan dengan melihat berbagai peraturan perundangundangan yang sederajat dan mengatur bidang yang sama atau terkait. Selain itu juga harusmemperhatikankronologissesuaiurutanwaktuditetapkanperaturanperundangundangan.

Adapun ketentuan dalam Rancangan Peraturan Pemerintah tentang Harmonisasi Dan Sinkronisasi Peraturan Perundang-Undangan Di Bawah Undang-Undang yang terkait yaitu:

- Pasal 1 ayat (2):

"Harmonisasi dan Sinkronisasi Peraturan Perundang-Undangan di bawah UndangUndang yang selanjutnya disebut dengan Harmonisasi dan Sinkronisasi adalah persidangan yang diselenggarakan dengan tujuan untuk memeriksa, menganalisis, dan mengevaluasi materi muatan Peraturan Perundang-Undangan di bawah Undang-Undang yang bertentangan dengan Peraturan Perundang-undangan yang lebih tinggi atau bertentangan dengan Putusan Pengadilan".13

- Pada Pasal 2:

(2) Harmonisasi dan sinkronisasi peraturan daerah atau peraturan kepala daerah dilakukan Kementerian Bersama dengan Kementerian Dalam Negeri dan Kementerian/Lembaga lainnya yang terkait.

(3) Dalam mengoordinasikan dan melaksanakan harmonisasi dan sinkronisasi sebagaimana dimaksud pada ayat (1) dan ayat (2), Menteri menetapkan Pokja. ${ }^{14}$

- Pasal 3:

(1) Pokja sebagaimana dimaksud dalam Pasal 2 ayat (3) melaksanakan harmonisasi dan sinkronisasi melalui panel persidangan yang keanggotaannya berasal dari kementerian/lembaga terkait, pakar/ahli, perancang peraturan perundangundangan, kalangan professional, dan praktisi.

(2) Pokja sebagaimana dimaksud pada ayat (1) memiliki tugas dan fungsi untuk: a. memeriksa, menganalisis dan memutuskan materi muatan peraturan perundangundangan yang lebih tinggi atau bertentangan dengan putusan pengadilan; dan

\footnotetext{
${ }^{10}$ Ahmad Fikri Hadin \& Muhammad Erfa Redhani, 2017, Simplikasi Peraturan Derah Sejenis Dalam Upaya Merampingkan Regulasi, Biro Pengkajian, Ibid., hlm. 7.

${ }^{11}$ Erick Sepria, op.cit. hlm. 140.

${ }^{12}$ Ibid, hlm. 140-141.

${ }^{13}$ Pasal 1 ayat (2) Rancangan Peraturan Pemerintah Tentang Harmonisasi Dan Sinkronisasi Peraturan Perundang-Undangan Di Bawah Undang-Undang.

${ }^{14}$ Ibid., Pasal 2.
} 
b. menyampaikan usulan rekomendasi kepada Menteri berdasarkan hasil putusan pokja.

(3) Ketentuan lebih lanjut mengenai kedudukan, susunan keanggotaan Pokja, dan tata cara persidangan sebagaimana dimaksud pada ayat (1) diatur dengan Peraturan Menteri. ${ }^{15}$

- Pasal 9 ayat (2):

Perubahan atau pencabutan Peraturan Daerah atau Peraturan Kepala Daerah hasil harmonisasi dan sinkronisasi sebagaimana dimaksud dalam Pasal 6 harus ditindak lanjuti oleh pemerintahan daerah paling lama 3 (tiga) bulan sejak surat Menteri Dalam Negeri diterima. ${ }^{16}$

Berdasarkan penjelasan dari istilah "harmonisasi" dan "sinkronisasi" oleh para pakar hukum. maka dapat disimpulkan bahwa dua kegiatan tersebut dapat dilakukan pada saat pembentukan peraturan maupun bagi peraturan yang sedang berlaku. Akan tetapi berdasarkan Rancangan Peraturan Pemerintah tentang Harmonisasi Dan Sinkronisasi Peraturan Perundang-Undangan di Bawah Undang-Undang mekanisme tersebut hanya berlaku bagi peraturan perundang-undangan bukan rancangan peraturan perundangundangan. Inilah mengapa kehadiran Pasal 181 ayat (2) Bab XIII Undang-Undang Nomor 11 Tahun 2020 tentang Cipta Kerja dinilai sebagai upaya merumuskan kembali substansi norma pengujian peraturan daerah melalui model executive review? Mengapa harmonisasi dan sinkronisasi peraturan daerah dapat dikatakan sebagai model executive review? Ada 3 (tiga) point yang disimpulkan oleh peneliti dalam rumusan terkait harmonisasi dan sinkronisasi yaitu: pertama, kegiatan tersebut tidak dibatasi pada suatu rancangan peraturan daerah akan tetapi juga pada peraturan daerah yang sedang berlaku. Kedua, kegiatan tersebut dilakukan oleh pemerintahan (bidang eksekutif). Hal tersebut dapat dilihat dari adanya pembentukan Pokja oleh Menteri. Ketiga, perubahan atau pencabutan peraturan daerah tersebut berdasarkan surat dari Menteri Dalam Negeri.

Meskipun sebelumnya kewenangan executive review ini sudah dibatalkan oleh Mahkamah Konstitusi melalui putusan Mahkamah Konstitusi Nomor 137/PUUXIII/2015 dan Putusan Mahkamah Konstitusi Nomor 56/PUU-XIV/2016. Melalui Putusan Mahkamah Konstitusi Nomor 137/PUU-XIII/2015 menyatakan bahwa Pasal 251 Undang-Undang Nomor 23 Tahun 2014 tentang Pemerintahan Daerah terkait dengan kewenangan pembatalan peraturan daerah Kabupaten/Kota tidak lagi bisa dibatalkan oleh Menteri Dalam Negeri atau Gubernur. Mahkamah Konstitusi dalam amar putusannya menyatakan bahwa frasa "peraturan daerah kabupaten/kota dan" dalam ketentuan Pasal 251 ayat (2) dan (4), frasa "peraturan daerah kabupaten/kota dan/atau" dalam Pasal 251 ayat (3), dan frasa "penyelenggara pemerintahan daerah kabupaten/kota tidak dapat menerima keputusan pembatalan peraturan daerah kabupaten/kota dan" dan frasa "peraturan daerah kabupaten/kota atau" dalam Pasal 251 ayat (8) Undang-Undang Nomor 23 Tahun 2014 tentang Pemerintahan Daerah bertentangan dengan UUD NRITahun 1945 dan tidak mempunyai kekuatan hukum yang mengikat. ${ }^{17}$ Adapun Mahkamah Konstitusi melalui Putusan Nomor 56/PUU-XIV/2016 yang menyatakan bahwa frasa "peraturan daerah provinsi dan" dalam Pasal 251 ayat (1) dan ayat (4), frasa "peraturan daerah provinsi dan" dalam Pasal 251 ayat (7), serta Pasal 251 ayat (5) Undang- Undang Nomor 23 Tahun 2014 tentang Pemerintahan Daerah

\footnotetext{
${ }^{15}$ Ibid., Pasal 3.

${ }^{16}$ Ibid., Pasal 9 ayat (2).

${ }^{17}$ Amar Putusan Mahkamah Konstitusi Nomor 137/PUU-XIII/2015, hlm. 211.
} 
bertentangan dengan UUD NRI Tahun 1945 dan tidak mempunyai kekuatan hukum mengikat. ${ }^{18}$ Berdasarkan 2 (dua) putusan tersebut dapat dilihat bahwa Mahkamah Konstitusi hanya membatalkan norma pembatalan peraturan daerah provinsi dan peraturan daerah kabupaten/kota akan tetapi tidak membatalkan ketentuan mengenai pembatalan peraturan kepala daerah baik provinsi maupun kabupaten/kota. Lantas untuk menjawab apakah kehadiran Pasal 181 ayat (2) Undang-Undang Nomor 11 Tahun 2020 tentang Cipta Kerja ini merupakan upaya untuk mengingkari konstitusi, maka perlu menjabarkan analisa berdasarkan teori kewenangan.

Pentingnya pembahasan mengenai kewenangan dalam konteks hukum administrasi negara membuat F.A.M Stroink dan J.G. Steenbeek menyebutnya sebagai konsep inti dalam Hukum Tata Negara dan Hukum Administrasi Negara. ${ }^{19}$ Menurut Bagir Manan, wewenang dalam bahasa hukum tidak sama dengan kekuasaan (macht). Kekuasaan hanya menggambarkan hak untuk berbuat atau tidak berbuat. Dalam hukum, wewenang sekaligus berarti hak dan kewajiban (rechten en plichten). ${ }^{20}$ Sementara A. Gunawan Setiardja mengutip konsep kekuasaan yang berkaitan dengan hukum oleh Max Weber yang menyebutnya sebagai kewenangan rasional atau legal yakni wewenang yang berdasarkan suatu sistem hukum yang dipahami sebagai suatu kaidah yang telah diakui serta dipatuhi oleh masyarakat bahkan diperkuat oleh negara. ${ }^{21}$ Hal tersebut dapat dipahami bahwa dalam konteks negara hukum menempatkan asas legalitas sebagai sendi utama dalam penyelenggaraan negara.

Asas legalitas tidak hanya digunakan dalam hukum pidana tetapi juga dalam hukum administrasi negara. Legalitas dalam hukum administrasi negara memiliki makna "Dat het bestuur aan de wet is onderworpen" (bahwa Pemerintah tunduk kepada undangundang) atau "Het legaliteitsbeginsel houdt in dat alle (algemene) de burgers bindende bepalingen op de wet moeten berusten "(asas legalitas menentukan bahwa semua ketentuan yang mengikat warga negara harus didasarkan pada undang-undang). Asas legalitas ini merupakan prinsip negara hukum yang sering dirumuskan dengan ungkapan "Het beginsel van wetmatigheid van bestuur" yakni keabsahan pemerintahan. ${ }^{22}$ Het beginsel van wetmatigheid van bestuur mengandung 3 (tiga) aspek: pertama, aspek negatif yang menentukan bahwa tindakan pemerintah tidak boleh bertentangan dengan undangundang. Kedua, aspek formal-positif menentukan bahwa pemerintah hanya memiliki kewenangan tertentu sepanjang diberikan atau berdasarkan undang-undang. Ketiga, aspek materiil-positif menentukan bahwa undang-undang memuat aturan umum yang mengikat Pemerintahan. Hal ini berarti bahwa kewenangan itu harus memiliki dasar perundang-undangan dan juga bahwa kewenangan itu isinya ditentukan normanya oleh undang-undang. ${ }^{23}$ Dengan demikian dapat dipahami bersama bahwa kewenangan merupakan bagian dari kekuasaan yang telah dilembagakan atau dilegalkan. Adanya hubungan erat antara kekuasaan dan kewenangan maka perlu dibatasi dan diatur sedemikian rupa untuk mencegah terjadinya penyalahgunaan wewenang yang merupakan bagian dari kekuasaan tersebut.

Perolehan kewenangan berdasarkan peraturan perundang-undangan tersebut lebih lanjut dijelaskan oleh Indroharto bahwa sumber wewenang dapat diperoleh secara atribusi, delegasi dan mandat yang masing-masing dijelaskan sebagai berikut:

\footnotetext{
${ }^{18}$ Amar Putusan Mahkamah Konstitusi Nomor 56/PUU-XIV/2016, hlm. 102.

${ }^{19}$ Ridwan HR, 2014, Hukum Administrasi Negara, Rajawali Pers, Jakarta, hlm. 99.

${ }^{20}$ Ibid.,

${ }^{21}$ Bambang Waluyo, 2016, Penegakan Hukum Di Indonesia, Sinar Grafika, Jakarta Timur, hlm. 211.

${ }^{22}$ Ridwan HR, Op.cit. hlm. 91.

${ }^{23}$ Ibid, hlm. 92
} 
"Wewenang yang diperoleh secara "atribusi", yaitu pemberian wewenang pemerintahan yang baru oleh suatu ketentuan dalam peraturan perundang-undangan. Jadi disini dilahirkan/diciptakan suatu wewenang pemerintah baru". Pada delegasi terjadilah pelimpahan suatu wewenang yang telah ada oleh Badan atau Jabatan Tata Usaha Negara yang telah memperoleh suatu wewenang pemerintahan secara atributif kepada Badan atau jabatan TUN lainnya. Jadi, suatu delegasi selalu didahului oleh adanya sesuatu atribusi wewenang. Pada mandat, disitu tidak terjadi suatu pemberian wewenang baru maupun pelimpahan wewenang dari Badan atau jabatan TUN yang satu kepada yang lain. $^{24}$

Adapun Philipus M. Hadjon menjelaskan bahwa sumber perolehan kewenangan yaitu:

"Setiap tindakan pemerintahan disyaratkan harus bertumpu atas kewenangan yang sah. Kewenangan itu diperoleh melalui tiga sumber, yaitu atribusi, delegasi dan mandat. Kewenangan atribusi lazimnya digariskan melalui pembagian kekuasaan negara oleh undang-undang dasar. Adapun kewenangan delegasi dan mandat adalah kewenangan yang berasal dari "pelimpahan"25

Mengacu pada pendapat diatas maka dapat dipahami bahwa kewenangan yang diperoleh secara atribusi merupakan kewenangan asli sedangkan kewenangan yang diperoleh secara delegasi dan mandat merupakan kewenangan yang berasal dari pelimpahan kewenangan asli. Sehingga dalam hal ini penulis berpandangan bahwa sudah semestinya kewenangan secara delegasi dan mandat tidak mendegradasikan kewenangan asli (atribusi).

Adapun analisis mengenai ketentuan Pasal 181 Bab XIII Undang-Undang Nomor 11 Tahun 2020 tentang Cipta Kerja sebagai berikut: pertama, Mahkamah Konstitusi merupakan lembaga negara yang dibentuk dan diberikan kewenangan oleh UUD NRI Tahun 1945 sehingga Mahkamah Konstitusi menurut Jimly Asshidiqie merupakan organ lapis pertama atau lembaga tinggi negara. ${ }^{26}$ Salah satu kewenangan dari Mahkamah Konstitusi menurut Pasal 24C Ayat (1) UUD NRI Tahun 1945 adalah mengadili pada tingkat pertama dan terakhir yang putusannya bersifat final untuk menguji undangundang terhadap Undang-Undang Dasar. Dengan demikian dapat dipahami bersama bahwa putusan Mahkamah Konstitusi Nomor 137/PUU-XIII/2015 dan Putusan Mahkamah Konstitusi Nomor 56/PUU-XIV/2016 merupakan putusan yang lahir dari kewenangan atribusi yang diperoleh oleh Mahkamah Konstitusi dari UUD sebagai the guardian of constitution dan sebagai the final interpreter constitution. Akan tetapi memang demikian, meskipun putusan Mahkamah Konstitusi bersifat final akan tetapi seringkali juga putusan tersebut tidak direspon secara positif bahkan seringkali putusan tersebut mendapat tantangan sengit dari aktor non-yudisial. ${ }^{27}$ Padahal Mauro Cappelletti menyatakan bahwa keyakinan pada pengadilan konstitusional maupun pengadilan umum sebagai jaminan yang efisien untuk efektivitas dan penegakan hukum yang lebih tinggi melalui peninjauan kembali merupakan ciri khas dari gagasan negara hukum. ${ }^{28}$

\footnotetext{
${ }^{24}$ Bambang Waluyo, op.cit, hlm. 215-216.

${ }^{25}$ Ibid., hlm. 217.

${ }^{26}$ Novendri M. Nggilu, 2015, Hukum dan Teori Konstitusi (Perubahan Konstitusi Yang Partisipatif Dan Populis), UII Press, Jogjakarta, hlm. 61.

${ }^{27}$ Jaelani, Abdul Kadir, dkk, Executability Of The Constitutional Court Decision Regarding Grace Period In The Formulation Of Legislation, Vol. 28 No. 15 Edisi 2019, https://scholar.google.co.id/citations?view_op = view_citation\&hl=id\&user = 4kOG858AAAAJ\&citation_for_view = 4kOG858AAAAJ:IWHjjKOFINEC, ākses 25 Juli 2021.

${ }^{28}$ Lusting, Doren and J.H.H. Weiler, Judicial Review In The Contemporary World-Retrospective And Prospective, Vol. 16 No. 2 Edisi Juni 2018, https://academic.oup.com/icon/article/16/2/315/5036485?login = trueJournal, diakses 18 Maret 2021.
} 
Perumusan norma pada pasal tersebut merupakan upaya untuk menghidupkan kembali norma yang telah diputuskan oleh Mahkamah Konstitusi melalui Putusan Mahkamah Konstitusi Nomor 137/PUU-XIII/2015 dan Putusan Nomor 56/PUU-XIV/2016. Padahal berdasarkan penjelasan Pasal 10 ayat (1) Undang-Undang Mahkamah Konstitusi menyatakan bahwa putusan Mahkamah Konstitusi adalah setara dengan undangundang, putusan tersebut langsung memperoleh kekuatan hukum tetap sejak diucapkan dan tidak ada upaya hukum yang dapat ditempuh. Sifat final dalam putusan tersebut mempunyai kekuatan hukum mengikat (final and binding). ${ }^{29}$ Selanjutnya mengutip pendapat dari Aan Eko Widiarto yang menyatakan bahwa:

"Putusan-putusan Mahkamah Konstitusi yang merupakan bagian proses dan mekanisme checks and balances dalam bidang legislasi, yang menurut konstitusi merupakan putusan yang final and binding, dan dengan demikian mengikat lembaga Negara dan harus diimplementasikan, dengan sengaja tidak dipatuhi, merupakan perlawanan balik (strike back), dengan cara yang amat kasar, yaitu mengundangkan kembali norma-norma yang telah ditegaskan Mahkamah Konstitusi bertentangan dengan UUD 1945 dan tidak mempunyai kekuatan hukum mengikat. Hal demikian merupakan pelanggaran konstitusi yang dilakukan secara terang-terangan, dan pelanggaran sumpah jabatan dan juga merupakan contempt of court". ${ }^{0}$

Maka sudah seharusnya baik legislatif maupun eksekutif ketika membentuk norma baru hendaknya mengacu kepada putusan-putusan Mahkamah Konstitusi yang terkait dengan norma yang akan dibentuk. Dengan demikian efisiensi dan efektifitas dari suatu norma yang dibentuk dapat terwujud. Sebagaimana yang kita ketahui bersama bahwa tujuan dibentuk undang-undang cipta kerja ini adalah untuk menyederhanakan kondisi hyper regulation yang ada di Indonesia saat ini. Sehingga harapannya jangan sampai kehadiran norma dalam undang-undang ini justru terlihat sebagai benang kisut yang justru akan menimbulkan permasalahan baru.

Kedua, berdasarkan ketentuan Pasal 24A ayat (1) UUD NRI Tahun 1945 Mahkamah Agung berwenang untuk menguji peraturan perundang-undangan dibawah undangundang terhadap undang-undang. Dengan demikian dapat dipahami bersama bahwa Mahkamah Agung merupakan lembaga tinggi negara yang diberikan kewenangan oleh UUD serta dikuatkan kembali oleh kedua putusan Mahkamah Konstitusi tersebut. Pada pembahasan teori kewenangan telah dijelaskan bahwa kewenangan delegasi dan/atau mandat tidak dapat mendegradasikan kewenangan asli. Pada Bab III tentang Kekuasaan Pemerintahan dan Bab V tentang Kementerian Negara dalam UUD NRI Tahun 1945 tidak ada satu pasal pun yang menyebutkan adanya kewenangan executive review yang dimiliki oleh lembaga eksekutif dan kementerian.

Adapun point argumentasi pihak Pemerintah sebelum kehadiran 2 (dua) putusan Mahkamah Konstitusi yang membatalkan kewenangan Menteri Dalam Negeri dan Gubernur untuk membatalkan peraturan daerah provinsi dan kabupaten/kota yaitu adanya klaim bahwa kewenangan tersebut diberikan sebagai bentuk pengawasan pemerintah pusat terhadap pemerintah daerah. Argumentasi selanjutnya ialah sebagai solusi untuk menutupi kelemahan pengawasan peraturan daerah melalui judicial review

${ }^{29}$ Febriansyah Ramadhan, 2020,Pola Penalaran Hukum Putusan Mahkamah Konstitusi Mengenai Undang-Undang Pengadilan HAM Ditinjau Dari Perspektif Upaya Penyelesain Pelanggaran HAM Berat Masa Lalu, Tesis, Malang Magister Ilmu Hukum Universitas Brawijaya, hlm 12.

${ }^{30}$ Aan Eko Widiarto, Ketidakpastian Hukum Kewenangan Lembaga Pembentuk Undang-Undang Akibat Pengabaian Putusan Mahkamah Konstitusi Legal Uncertainty of the Authority of Law-Making Institution as the Result of Denial of Constitutional Court Decision, Vol. 12 No. 4 Edisi Desember 2015, https://jurnalkonstitusi.mkri.id/index.php/jk/article/view/1244, hlm 747, diakses 12 Januari 2021. 
yang bersifat pasif. Berdasarkan Laporan Tahunan Mahkamah Agung, Mahkamah hanya menerima dan memutus 10 (sepuluh) permohonan pengujian peraturan daerah dari 542 (lima ratus empat puluh dua) daerah otonom yang tentunya akan sangat banyak peraturan daerah yang luput dari pengawasan apabila pemerintah tidak diberikan kewenangan untuk mengawasi peraturan daerah. ${ }^{31}$

Terkait dengan pengawasan produk hukum yang dilakukan oleh Pemerintah pusat kepada pemerintah daerah maka penting untukk memperhatikan bentuk pengawasan yang dimaksudkan. Secara teoritis menurut Bagir Manan paling tidak, ada dua bentuk utama pengawasan terhadap suatu satuan bestuur yang lebih rendah oleh satuan bestuur yang lebih tinggi yaitu: "pengawasan administratif (administratief toezicht) dan banding administratif (administratiefberoep). Pengawasan administratif (administratief toezicht) dapat berupa pengawasan preventif (preventief touzicht) dan pengawasan represif (repressief toezicht). ${ }^{32}$ Dalam hal ini executive review merupakan bagian dari pengawasan represif dalam satuan bestuur. Akan tetapi karena UUD telah mengatur mengenai pengawasan represif oleh lembaga yudikatif dalam rangka mewujudkan check and balances system antar lembaga negara maka alangkah baiknya dalam satuan bestuur untuk menerapkan pengawasan preventif untuk mengawal dan mengawasi perda. Gagasan tersebut sejalan dengan pendapat dari Aswanto yang menyatakan bahwa pembatalan perda oleh Kementerian Dalam Negeri sebenarnya menyalahi dari segi teori produk legislatif tidak boleh dibatalkan oleh eksekutif dan tidak semestinya pembatalan perda tersebut melalui keputusan akan tetapi cukup Departemen Dalam Negeri memberikan masukan terhadap kajian mereka tentang perda yang diasistensi dari daerah. ${ }^{33}$

Selanjutnya pengawasan peraturan daerah melalui executive review merupakan solusi bagi kelemahan Mahkamah Agung dalam menerima dan menguji peraturan daerah tentunya berkaitan dengan pembahasan mengenai efektifitas penegakan hukum di Indonesia. Mengutip pendapat dari Posner mengenai sarana atau fasilitas pendukung penegakan hukum yang dianalogikan jalan bebas hambatan untuk mengatasi kemacetan lalu lintas yang menyatakan bahwa:

"Adanya hambatan penyelesaian perkara bukanlah semata-mata disebabkan karena banyaknya perkara yang harus diselesaikan, sedangkan waktu untuk mengadilinya atau menyelesaikannya adalah terbatas. Kalau jalan bebas hambatan tersebut sudah selesai dibangun dan pemakai jalan mulai menikmatinya, maka akan timbul keinginan yang kuat untuk selalu mempergunakan jalan bebas hambatan tersebut, sehingga nantinya akan timbul kemacetan lagi. Oleh karena itu, yang perlu diperhitungkan tidaklah hanya biaya yang harus dikeluarkan apabila terjadi hambatan di dalam penyelesaian perkara, akan tetapi yang juga perlu diperhatikan adalah biaya yang harus ada kalau hambatan penyelesaian perkara itu tidak terjadi lagi sehingga dimanfaatkan secara maksimal oleh para pencari keadilan. ${ }^{34}$

${ }^{31}$ Agus Sahbani, Ini Argumentasi Pemerintah Mengenai Pembatalan Perda, http://m.hukumonline.com/berita/ baca/lt57cf4fb3b79b1/ini-argumentasi-pemerintah-mengenai-pembatalan-perda , diakses 24 Juli 2021.

32 Yuswanto dan M. Yasin Al- Arif, Diskursus Pembatalan Peraturan Daerah Pasca Putusan MK No. 137/PUU-XIII/2015 dan No. 56/PUU-XIV/2016, Vol. 15 No. 4 Edisi Desember 2018, https://jurnalkonstitusi.mkri.id/index.php/jk/article/view/1542, hlm. 718, diakses 12 Januari 2021.

${ }^{33}$ Radix Jeremia, Kewenangan Mendagri Membatalkan Perda Dalam Kedudukannya Sebagai Lembaga Eksekutif , Jurnal Hukum Bisnis dan Administrasi Negara, Vol. 3 No. 2 Edisi Februari 2018, hlm. 19.

${ }^{34}$ Soerjono Soekanto, 2014, Faktor-Faktor Yang Mempengaruhi Penegakan Hukum, PT Raja Grafindo Persada Jakarta, hlm. 40-41. 
Terkait dengan pendapat tersebut menurut peneliti alangkah sebaiknya pengawasan yang dilakukan oleh Pemerintah Pusat kepada Pemerintah Daerah terkait dengan peraturan daerah hanya sebatas pada rancangan peraturan daerah saja. Hal tersebut tentunya dapat menekan biaya dalam pembuatan suatu peraturan daerah agar tidak siasia semata bahkan harus berujung pembatalan yang sebelumnya melalui persetujuan pemerintah pula. Sehingga peneliti berkesimpulan selama norma-norma terkait dengan judicial review dalam UUD belum diadakan perubahan maka kewenangan untuk pembatalan peraturan dibawah undang-undang terhadap undang-undang tetap berada ditangan Mahkamah Agung dan Pemerintah dapat menerapkan executive preview sebagai bentuk pengawasan preventif.

Ketiga, karena kedua kewenangan tersebut bersumber dari UUD di dalamnya memuat norma-norma dasar (groundnorm). Berdasarkan Pasal 7 Undang-Undang Nomor 12 Tahun 2011 tentang Pembentukan Peraturan Perundang-undangan bahwa norma tertinggi dalam sistem peraturan perundang-undangan di Indonesia adalah UUD NRI Tahun 1945. Sesuai dengan stufenbau theorie yang dikemukakan oleh Hans Kelsen bahwa adanya hubungan antara norma yang mengatur pembentukan norma lain dengan norma lain lagi dapat digambarkan sebagai hubungan antara "superordinasi" dan "subordinasi" yang merupakan kiasan keruangan. Norma yang menentukan pembentukan norma lain adalah norma yang lebih tinggi sedangkan norma yang dibentuk menurut peraturan ini adalah norma yang lebih rendah. Adanya regressus (rangkaian proses pembentukan hukum) dimana norma yang rendah didasarkan pada norma yang tertinggi dan selanjutnya ini kemudian diakhiri oleh suatu norma dasar tertinggi yang menjadi dasar tertinggi dari validitas keseluruhan tatanan hukum, membentuk suatu kesatuan tatanan hukum ini. ${ }^{35}$ Dengan demikian dapat dipahami bersama bahwa validitas suatu norma tergantung kepada norma yang lebih tinggi. Sehingga dalam hal ini dapat dinyatakan bahwa norma dalam ketentuan Pasal 181 ayat (2) Bab XIII Undang-undang Cipta Kerja tersebut tidak valid sehingga tidak menutup kemungkinan jika diajukan kembali judicial review kepada Mahkamah Konstitusi akan dinyatakan inkonstitusional. Jika memang demikian berarti pembentukan norma dalam undang-undang ini tentunya tidak efektif dan efisien sebagaimana yang dimaksud oleh pemerintah.

\section{SIMPULAN}

Ketentuan Pasal 181 ayat (2) Bab XIII Undang-Undang Nomor 11 Tahun 2020 tentang Cipta Kerja mengatur mengenai mekanisme harmonisasi dan sinkronisasi peraturan daerah oleh Pemerintah. Sebelumnya, Mahkamah Konstitusi melalui 2 (dua) putusannya yaitu Putusan Mahkamah Konstitusi Nomor 137/PUU-XIII/2015 dan Putusan Mahkamah Konstitusi Nomor 56/PUU-XIV/2016 membatalkan norma mengenai kewenangan Pemerintah yang dalam hal ini Kementerian Dalam Negeri dan Gubernur untuk membatalkan peraturan daerah tingkat provinsi dan kabupaten/ kota melalui mekanisme executive review karena dinilai bertentangan dengan UUD NRI Tahun 1945 serta tidak memiliki kekuatan hukum yang mengikat. Adapun mekanisme harmonisasi dan sinkronisasi peraturan perundang-undangan yang dimaksud pada Pasal 181 ayat (2) Bab XIII Undang-Undang Nomor 11 Tahun 2020 tentang Cipta Kerja merupakan sebuah upaya untuk menghidupkan kembali pasal yang telah dinyatakan inkonstitusional karena memiliki kesamaan dengan executive review. Selain itu kehadiran mekanisme harmonisasi dan sinkronisasi peraturan daerah oleh pemerintah ini

\footnotetext{
${ }^{35}$ Hans Kelsen, 2018, Teori Umum Tentang Hukum Dan Negara, Nusa Media, Bandung, hlm 179.
} 
menimbulkan dualism kewenangan menguji peraturan daerah dengan model executive review dan judicial review. Sehingga perlu pembagian pengawasan produk hukum daerah yakni pengawasan pemerintah pusat menggunakan pendekatan preventif dalam rangka mewujudkan efektifitas penegakan hukum di Indonesia.

\section{DAFTAR PUSTAKA}

\section{Buku}

Ahmad Fikri Hadin, \& Muhammad Erfa Redhani, (2017), Simplikasi Peraturan Derah Sejenis Dalam Upaya Merampingkan Regulasi, Biro Pengkajian (Ed.), Strategi Perampingan Dan Harmonisasi Regulasi Pusat Dan Daerah, Majelis Permusyawaratan Rakyat Republik Indonesia, Jakarta.

Almas Sidda Bahiya, (2020), Executive Review Sebagai Langkah Peningkatan Kualitas Peraturan Daerah di Indonesia, Moechthar Oemar (Ed), Eksistensi, Fungsi dan Tujuan Hukum Dalam Perspektif Teori dan Filsafat Hukum, Kencana, Jakarta.

Bambang Waluyo, (2016), Penegakan Hukum Di Indonesia, Sinar Grafika, Jakarta.

Eka Nam Sihombing, (2018), Hukum Kelembagaan Negara, Ruas Media, Yogyakarta. Hans Kelsen, (2018), Teori Umum Tentang Hukum Dan Negara, Nusa Media, Bandung.

Novendri M. Nggilu, (2015), Hukum dan Teori Konstitusi (Perubahan Konstitusi Yang Partisipatif Dan Populis), UII Press, Jogjakarta.

Ridwan HR, (2014), Hukum Administrasi Negara (Edisi Revisi), Rajawali Pers, Jakarta.

Rio Christiawan, (2021), Omnibus Law Teori Dan penerapannya, Cet. Ke-1, Sinar Grafika, Jakarta.

Sepria, Erik, (2017), Sinkronisasi dan Harmonisasi Pembentukan Regulasi Pusat Dengan Daerah Dalam Rangka Penataan Regulasi Sebagai Pelaksanaan Otonomi Daerah di Indonesia, Biro Pengkajian (Ed.), Strategi Perampingan Dan Harmonisasi Regulasi Pusat Dan Daerah, Majelis Permusyawaratan Rakyat Republik Indonesia, Jakarta.

Soerjono Soekanto, (2014), Faktor-Faktor Yang Mempengaruhi Penegakan Hukum, PT Raja Grafindo Persada, Jakarta.

\section{Jurnal}

Doren Lusting and J.H.H. Weiler, (2018), Judicial Review In The Contemporary WorldRetrospective And Prospective, Journal International Constitutional Law, Vol. 16, Issue 2, Oxford Academic United Kingdom.

Eko Widiarto, Aan, Ketidakpastian Hukum Kewenangan Lembaga Pembentuk UndangUndang Akibat Pengabaian Putusan Mahkamah Konstitusi Legal Uncertainty of the Authority of Law-Making Institution as the Result of Denial of Constitutional Court Decision, Jurnal Konstitusi, Volume 12, Mahkamah Konstitusi, 2015.

Jeremia Radix, Kewenangan Mendagri Membatalkan Perda Dalam Kedudukannya Sebagai Lembaga Eksekutif, Jurnal Hukum Bisnis dan Administrasi Negara, Vol.

3 No. 2, Fakultas Hukum Universitas DR. Soetomo, Surabaya, 2017.

Kadir Abdul Jaelani, dkk, Executability Of The Constitutional Court Decision Regarding 
Grace Period In The Formulation Of Legislation, International Journal of Advanced Science and Technology, Vol. 28, No. 15, Science and Engineering Research Support Society, Australia, 2019.

Yuswanto dan M. Yasin A1- Arif, Diskursus Pembatalan Peraturan Daerah Pasca Putusan MK No. 137/PUU-XIII/2015 dan No. 56/PUU-XIV/2016, Vol. 15, No. 4, Jurnal Konstitusi, Mahkamah Konstitusi, Indonesia, 2018.

Skripsi, Tesis, Dan Disertasi

Nurhasan, Muhamad, Pembatalan Kewenangan Executive Review Pada Kementerian Dalam Negeri (Studi Analisis Putusan Mahkamah Konstitusi Nomor 56/PUUXIV/2016), Skripsi, Fakultas Syariah Dan Hukum Universitas Islam Syarif Hidayatullah, 2018.

Ramadhan, Febriansyah, Pola Penalaran Hukum Putusan Mahkamah Konstitusi Mengenai Undang-Undang Pengadilan HAM Ditinjau Dari Perspektif Upaya Penyelesain Pelanggaran HAM Berat Masa Lalu, Tesis, Magister Ilmu Hukum Universitas Brawijaya, 2020.

\section{Perundang-undangan}

Undang-Undang Dasar Negara Republik Indonesia Tahun 1945.

Undang-Undang Republik Indonesia Nomor 12 Tahun 2011 tentang Pedoman Penyusunan Perundang-Undangan, Lembaran Negara Republik Indonesia Tahun 2011 Nomor 82, Tambahan Lembaran Negara Republik Indonesia Nomor 5234.

Nomor 11 Tahun 2020 tentang Cipta Kerja, Lembaran Negara Republik Indonesia Tahun 2020 Nomor 245, Tambahan Lembaran Negara Republik Indonesia Nomor 6573.

\section{Website}

Ady Thea DA, (2020), Ini Tujuh Dampak Negatif RUU Cipta Kerja Terhadap Publik, https://www.hukumonline.com/berita/baca/lt5f11d8eae4bba/ini-tujuhdampak-negatif-ruu-cipta-kerja-terhadap-publik/, diakses 10 September 2020.

Agus Sahbani, (2016), Ini Argumentasi Pemerintah Mengenai Pembatalan Perda, http://m.hukumonline.com/berita/baca/lt57cf4fb3b79b1/ini-argumentasipemerintah-mengenai-pembatalan-perda, diakses 24 Juli 2021.

Luqman Rimadi, (2016), 3.143 Perda yang Dibatalkan Bisa Dilihat di Situs Kemendagri, https://www.liputan6.com/news/read/2536897/3143-perda-yang-dibatalkanbisa-dilihat-di-situs-kemendagri, diakses 13 Oktober 2020. 